Original article

\title{
Chromatographic quantification of polyphenol in relation to potential antioxidant activity and isolation of DNA from in vitro cultivated Decalepis nervosa Wight \& Arn. leaf explant
}

\author{
M. Saifulla Khan*, Kuntal Das* and P. E. Rajasekharan* \\ Krupanidhi College of Pharmacy, \#12/1, Chikkabellandur, Carmelaram Post, Varthur Hobli, Bangalore-560035, India \\ *Division of Plant Genetic Resources, IIHR, Hessaraghatta Lake Post, Bangalore-560080, India
}

Received September 11, 2019: Revised November 2, 2019: Accepted November 5, 2019: Published online December 30 , 2019

\begin{abstract}
The objective of the present study was to perform in vitro micropropagation as well as the growth of callus from the leaf explant of Decalepis nervosa Wight \& Arn. (DN) (Family: Apocynaceae), a climber woody medicinal plant. Addition of silicon ( $\mathrm{Si}$ ) as sodium and potassium silicate in the MS media helped in fast micropropagation, callus development and organogenesis of the explant which was modified technique in plant tissue culture of the said plant. Silicon ion also helped in avoiding browning of callus. Therefore, an alternate in vitro tissue culture method was established using sodium silicate and potassium silicate using varying concentrations of $0.5,1.0,2.0,2.5,3.0$ and 3.5 $\mathrm{mg} / 1$ to overcome the challenges when compared with the normal MS media. Half strength MS medium supplemented with BAP at $0.2 \mathrm{mg} / 1$ and NAA at $2.5 \mathrm{mg} / 1$ gave callus growth in 21 days and resulted in more accumulation of gallic acid. Thereafter, direct rooting and shoots of meristem occurred with IBA and $\mathrm{Si}$ as sodium silicate (IBA at $2 \mathrm{mg} / \mathrm{land} \mathrm{Na}_{2} \mathrm{SiO}_{3}$ at $2.5 \mathrm{mg} / \mathrm{l})$, supplemented in half-strength MS media along with coconut water, within 18 days. Further, gallic acid in the methanol callus extract was estimated by the HPLC method and analyzed for antioxidant activity, using DPPH assay method. Finally, leaf DNA extraction was carried out (starting of genotype analysis) by CTAB (cetyl trimethylammonium bromide) method for purification of DNA and nanodrop method for quantification of the same. Finally, the results concluded that potassium silicate enhanced the production of phenolic content when analyzed by HPLC method, proved antioxidant activity as well as improved root formation in a very short time. Thereafter, single DNA pure band was identified and quantified which is essential for future research on new drug discovery.
\end{abstract}

Key words: Antioxidant, callus, chromatography, DNA, in vitro culture, silicates

\section{Introduction}

In biological research, plant tissue culture is an interesting, important and also challengeable experiment for the noble drug discovery. The technique has a high impact on increased plant secondary metabolites, easy isolation of constituents and genetic manipulation as per desired requirements. The plant tissue culture method not only helps in the enhancement of phytoconstituents but also helps in mass production of economically important plant species that may be any known cultivated plants or may be endangered plants. There are many forms of tissue culture techniques, in that callus culture and micropropagation are the well-known methods of interest for mass production (Dave and Purohit, 2002; Debnath et al., 2006).

Of late, Decalepis nervosa (DN) Wight \& Arn. Venter is among the species of Decalepis which became endangered plant species with medicinal liana of Apocynaceae. Though, the plant is distributed in

\footnotetext{
Author for correspondence: Dr. Kuntal Das

Professor, Department of Pharmacognosy and Phytochemistry, \#12/1, Krupanidhi College of Pharmacy, Chikkabelandur, Carmelaram Post, Varthur Hobli, Bangalore-560035, Karnataka, India

E-mail: drkkdsd@gmail.com

Tel.: +91-9632542846
}

Copyright () 2019 Ukaaz Publications. All rights reserved.

Email: ukaaz@yahoo.com; Website: www.ukaazpublications.com the Western Ghats regions of Tamil Nadu, Kerala, and Karnataka due to the over-exploitation and habitat loss, the plant is in high demand to the economic Indian market (Ionta, 2009; Udayan et al., 2013). The plant is climbing shrub, leaves are the simple opposite, with elliptic or elliptic-oblong and acute to acuminate shape. The roots of this plant are odorous, curvy and hard. Other species of Decalepis roots are aromatic odor and traditionally used in the preparation of pickles, flavoring principle (Murti and Seshadri 1941) and several Ayurvedic drug formulations (Anonymous, 2003), appetizer and blood purifier (Jacob, 1937). It was documented that tribal people use more than 9500 plant species for their various requirements among that for the medicinal purpose, they use more than 7500 species and remaining for food, fiber, and cordage, fodder, gum, resin and dyes (Anonymous, 1962; Anonymous, 2000). Hence, the demand for the plant is enormous and this leads to abundant procurement of the plant parts which created the existence of the same species. The overexploitation by destructive harvesting, habitat loss, limited pollinator, delayed seed germination, etc., resulted, the said plant become endangered in the natural habitat but still some species of the plant exists in the wild forest, especially in the Western Ghats regions of the South Indian zones. Hence, conservation of such a selected plant is essential for economic benefits. In the present study, a micropropagation protocol was 
developed for the said plant for mass propagation with high biomass yield. Many works of literatures revealed various micropropagation techniques for Decalepis hamiltonii and other Decalepis species (Bais et al., 2000; Giridhar et al., 2005), but no such literature is available on DN leaf in vitro culture. Thereafter, phenolic acid such as gallic acid is an important plant secondary metabolites which is present in the leaf of DN plant, shows many pharmacological activities such as an antioxidant, antimutagenic, lipid-lowering, antiatherosclerotic, anti-liver injury, anti-tumor, and anticarcinogenic, etc. (Jiang and Yang, 2010; Zhang et al., 2010). Hence, it is necessary to enhance the content of gallic acid in the DN leaf through in vitro culture. Application of silicon in plant tissue culture helps in early root formation, micropropagation, and accumulation of plant secondary metabolites. Many research works are proved earlier that the use of silicon compounds especially sodium, potassium, and calcium silicate improves organogenesis, embryogenesis, growth traits, morphological, and physiological characteristics of leaves and prevents oxidative phenolic browning in various plants (Sivanesan and Park, 2014). There are no reports on the in vitro culture of DN plant species. A polyphenolic compound such as gallic acid is present in the selected plant, and also silicate compounds help in accumulation of secondary plant constituents. Hence, an innovative protocol was designed and the present research was carried out with silicon-containing compounds with a combination of coconut water and other plant growth hormones for micropropagation and growth of the plant from stem under the aseptic condition as well as callus induction of the leaf disk. Further, estimation of a polyphenolic compounds such as gallic acid with its antioxidant study vis-a-vis DNA isolation, purification and quantification from plant callus were carried out.

\section{Materials and Methods}

\subsection{Procurement of DN plant}

Matured DN plants were procured from Western Ghats region of Tamil Nadu in month of April, 2018 by Dr. S. Gokul, PDF scholar of CIMAP, Bangalore and maintained in the department (Pharmacognosy and Phytochemistry, Krupanidhi College of Pharmacy, Bangalore, Herbarium number: KCP/KD-DN/398/2018) medicinal plant garden after authenticated by Dr. Rajasekharan P. E, Principal Scientist, Department of Plant Biotechnology, Indian Institute of Horticultural Research, Bangalore. Chemicals and plant hormones used in this present study were procured from Himedia Laboratories, Mumbai, India.

\subsection{Preparation of culture medium}

Murashige and Skoog (MS) basal medium (Murashige and Skoog, 1962) was used throughout the study. The basal medium was supplemented with various plant hormones with varying concentrations such as 1-naphthaleneacetic acid (NAA), indole-3butyric acid (IBA) and 6-benzylaminopurine (BAP) (0.1 to $3 \mathrm{mg} / \mathrm{l}), 1$ to $3 \%(\mathrm{w} / \mathrm{v})$ sucrose, media adjuvants such as coconut water $(3$ to 8 $\%, \mathrm{v} / \mathrm{v}$ ) and silicate compounds, viz., sodium and potassium silicate ( 0.5 to $3.5 \mathrm{mg} / \mathrm{l})$. The $\mathrm{pH}$ of the medium was adjusted to 5.6 to 5.8 . The medium was prepared with added 0.8 to $1.2 \%(\mathrm{w} / \mathrm{v})$ agar in $1 \mathrm{Lt}$ volume and then melted in a gas burner. The whole medium separately was distributed in various culture vessels, tubes and finally then sterilized in an autoclave at $15 \mathrm{Psi}$ and $121^{\circ} \mathrm{C}$, for $15 \mathrm{~min}$.

\subsection{Surface sterilization of explants}

Fresh young leaves of DN were selected, thoroughly washed in running tap water and $0.3 \%(\mathrm{v} / \mathrm{v})$ sodium hypochlorite with a few drops of "Teepol" for $5 \mathrm{~min}$. Then rinsed with double distilled water followed by a wash in running tap water. Then leaves were transferred to sterile laminar airflow cabinet and surface sterilized in $0.05 \%(\mathrm{w} / \mathrm{v})$ mercuric chloride $\left(\mathrm{HgCl}_{2}\right)$ solution for $5 \mathrm{~min}$ and rinsed thoroughly in sterile distilled water.

\subsection{Callus establishment and growth}

Surface sterilized tender leaves were cut into optimum size $(0.5$ to $1.0 \mathrm{~cm})$. Few leaf discs were aseptically placed into sterile culture vessels and tubes under aseptic area and incubated under the BOD incubator at $25 \pm 2{ }^{\circ} \mathrm{C}$. The night environment was maintained properly throughout the callus growth. Proliferated callus was subcultured in 10 to 15 days interval for further establishment. After establishment, $0.5 \mathrm{~g}$ of callus was transferred to fresh MS medium $(50 \mathrm{ml})$ supplemented with BAP and NAA $(0.1$ to $3 \mathrm{mg} / \mathrm{l})$, coconut milk (3 to $8 \%, \mathrm{v} / \mathrm{v})$.

\subsection{Micropropagation}

Meristem contained nodal segments ( $1 \mathrm{~cm}$ size) of DN plant was selected for micropropagation. Separately, the meristems are inoculated aseptically in test tubes $(25 \times 150 \mathrm{~mm})$ containing $20 \mathrm{ml}$ of MS medium with the respective sources and concentrations of silicate, then the vessels were maintained in a growth chamber at $25 \pm 2{ }^{\circ} \mathrm{C}$, an average irradiance of $51 \mu \mathrm{mol} / \mathrm{m}^{2} / \mathrm{s}$ and a darkness of $17 \mathrm{~h}$. The number of leaves, shoot length $(\mathrm{cm})$ and number of roots were measured in each case. Furthermore, Silicon concentration in leaves was identified with a scanning electron microscope and determined the content of $\mathrm{Si}$ in high yielded micropropagated plant that compared with low yielded micropropagated plant. For the method, the leaves were collected separately and oven-dried at $60^{\circ} \mathrm{C}$ temperature. Dried leaves samples were coarsely powdered and silicon content was estimated by the molybdenum-blue colorimetric method, described earlier (Gallo and Furlani, 1978).

\subsection{Extraction of callus}

$5 \mathrm{~g}$ of fresh callus was reflux with $50 \mathrm{ml}$ methanol for $6 \mathrm{hrs}$. Evaporated the methanol solvent and the viscous extract was collected for further experiment.

\subsection{HPLC analysis}

The amount of Gallic acid present in the callus extract was estimated by compared with normal plant hormone content MS medium and MS medium supplemented with silicon compound and plant hormone in HPLC.

Optimized conditions for chromatography

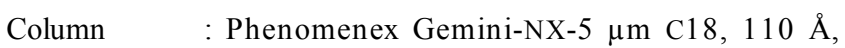
LC Column 250 x $4.6 \mathrm{~mm}$

Mobile phase : Methanol: water (60:40)

Injection valve : $7725 \mathrm{i}$ Rheodyne $20 \mu 1$, USA

Elution Type : Isocratic

Flow Rate : $1 \mathrm{ml} / \mathrm{min}$

Detection : UV at $203 \mathrm{~nm}$ 


\section{Standard preparation}

$5 \mathrm{mg}$ of standard Gallic acid (purity: 99.5\%) was taken in $5 \mathrm{ml}$ volumetric flask and make up the volume to $10 \mathrm{ml}$ with methanol (the concentration of this solution is $1 \mathrm{mg} / \mathrm{ml}$ ) and was sonicated (at frequency of $30 \mathrm{kHz}$ ) for 8 min then the solution was filtered using 0.45 micron Millipore filters.

\section{Sample preparation}

$1 \mathrm{mg}$ of the callus extract was dissolved in $1 \mathrm{ml}$ of methanol (Conc: $1 \mathrm{mg} / \mathrm{ml}$ ). The solution was a vortex for 5 mins. The sample was filtered using 0.45 -micron Millipore filters. $20 \mu 1$ of this sample was injected into the HPLC system.

\section{Calculation}

The percentage concentration:

= Sample area/ Standard area X Standard wt. /Sample wt. X Sample dilution /Standard dilution X purity of standard/100 x 100

\subsection{Antioxidant study}

2.8.1 DPPH (2,2-diphenyl-1-picrylhydrazyl hydroxyl) method

Callus methanol extract was estimated antioxidant activity by the DPPH method. This method is very basic and easy method for estimation of antioxidant nature of extract by spectrophotometric method at $517 \mathrm{~nm}$. The method followed as mentioned in earlier literature (Das et al., 2019) i.e., DPPH solution mixed with extract and kept for 30 minutes in dark for the reaction and finally absorbance measured against blank methanol. Thereafter, percentage inhibition of DPPH was calculated as:

$\%$ inhibition $=\frac{\mathrm{Abs}_{\text {blank }}-\mathrm{Abs}_{\text {sample }}}{\mathrm{Abs} \text { blank }} \times 100$

where, Abs $=$ Absorbance at UV $517 \mathrm{~nm}$

\subsection{Isolation of DNA from DN callus by CTAB}

The callus tissue is grinded in liquid nitrogen contained a few $\mathrm{mg}$ of polyvinylpyrrolidone. Further, $700 \mu 1$ of CTAB is added in extraction buffer and $10 \mu \mathrm{l}$ of $\beta$-mercaptoethanol for $0.5 \mathrm{gm}$ of tissue. Then kept at $60^{\circ} \mathrm{C}$ for $30-45 \mathrm{~min}$ and then an equal volume of chloroform: isoamylalcohol (24:1 ice cold) is added and mixed well. Thereafter, centrifuged at $8000 \mathrm{rpm}$ for 20 mins and then $4 \mu 1$ of RNase is added into that solution and incubated on a water bath at $65^{\circ} \mathrm{C}$ for 15 mins or $37^{\circ} \mathrm{C}$ for $1 \mathrm{~h}$ in the incubator. Then again the equal volume of chloroform: isoamylalcohol is added and centrifuged at $8000 \mathrm{rpm}$ for $10 \mathrm{~min}$. To the $2 / 3^{\text {rd }}$ volume of ice-cold isopropanol or double volume of ice-cold ethanol is added to the solution and kept at$70^{\circ} \mathrm{C}$. Further, centrifuged at $8000 \mathrm{rpm}$ for $15 \mathrm{~min}$ and precipitate is collected. Washed the pellet with $70 \%$ alcohol and air-dried, the pellet and resuspended the pellet in $10 \mathrm{mM}$ tris buffer and kept at $4^{\circ} \mathrm{C}$ for dissolving DNA. Finally, purified DNA was estimated (absorption measured) by nanodrop method by placed 21 of water as selected "Blank" after that placed another 2 lof water to confirm that the measure is 0 and then placed 21 of the sample. The ratio of the absorbance at 260: $280 \mathrm{~nm}$ and 260:230 nm $\left(\mathrm{A}_{260 / 280} ; \mathrm{A}_{260 / 230}\right)$ are used to assess the purity of Isolated DNA (Doyle and Doyle, 1987; Healey et al., 2014).

\subsection{Correlation study}

Yield, Si content in the leaf of DN was correlated with the estimated amount of the gallic acid present in the callus methanol extract.

\section{Statistical analysis}

Analysis of variance (ANOVA) and Duncan's multiple range test (Duncan, 1955) were performed. mean \pm SD was calculated for the number of roots and length of the shoot. The differences among averages of the recorded parameters for all treatments were tested for significance at $5 \%$ level $(p<0.05)$.

\section{Results}

\subsection{Callus initiation and elongation}

Various concentrations of plant hormones with sodium and potassium silicate supplemented MS medium were prepared and leaf disk of DN explant was established. It was resulted that potassium silicate $(2.5 \mathrm{mg} / \mathrm{l})$ and coconut water $(3 \mathrm{ml} / \mathrm{l})$ containing MS medium supplemented with BAP at $0.2 \mathrm{mg} / \mathrm{l}$ and NAA at $2.5 \mathrm{mg} / 1$ gave satisfactory initiation of callus in 21 days (Figure 1), whereas in same concentration, sodium silicate and coconut water $(2.5 \mathrm{ml} / \mathrm{l})$ containing MS medium supplemented with BAP at $0.3 \mathrm{mg} / 1$ and $\mathrm{NAA}$ at $2.0 \mathrm{mg} / 1$ gave maximum callus growth in 35 days of subcultured callus and thereafter, the growth decreased with increase in concentration. The result showed the highest callus growth with a fresh weight of $1.68 \mathrm{~g}$ with sodium silicate at $2.5 \mathrm{mg} / \mathrm{l}$ concentration in MS medium whereas the same was reduced $(1.23 \mathrm{~g})$ with potassium silicate at $2.5 \mathrm{mg} / \mathrm{l}$ concentration (Figure 2).

\subsection{Micropropagation and silicon content in leaf}

Various concentrations of silicate compounds such as sodium and potassium silicates were mixed in MS medium (Full and Half strength) supplemented with IBA and NAA (Auxin hormone for root growth) and coconut water $5 \% \mathrm{v} / \mathrm{v}$ (Cytokinin) were used for direct micropropagation from the DN meristem. It was observed that IBA at $2 \mathrm{mg} / 1$ and $\mathrm{Na}_{2} \mathrm{SiO}_{3}$ at $2.5 \mathrm{mg} / 1$ supplemented in half-strength MS media along with coconut water initiated roots and shoot within 18 days and improved the length of roots and shoots after 48 days of subculture. The number of leaves, shoot length $(\mathrm{cm})$ and number of roots was measured and resulted height number of leaves came 16 , with a length of shoot $7 \mathrm{~cm}$ and 9 numbers of roots with the same condition (Figure 3, Table 1).

The number of roots and length of the shoots is increased up to a certain concentration increase of the sodium and potassium silicate in the MS medium but the same is more significant in sodium silicate containing MS medium (Table 1). Interestingly, the number of leaves is decreased with an increased in concentration (Figure 4) for both the cases (IBA at $2 \mathrm{mg} / 1$ and $\mathrm{K}_{2} \mathrm{SiO}_{3}$ at $2.5 \mathrm{mg} / 1$ with coconut water and IBA at $2 \mathrm{mg} / 1$ and $\mathrm{Na}_{2} \mathrm{SiO}_{3}$ at $2.5 \mathrm{mg} / \mathrm{l}$ ). Thereafter, the accumulation of silicon content in leaves was higher in sodium silicate containing MS medium up to a certain concentration (at 2.5 $\mathrm{mg} / \mathrm{l}$ ) of plant growth than potassium silicate (Figure 5). 


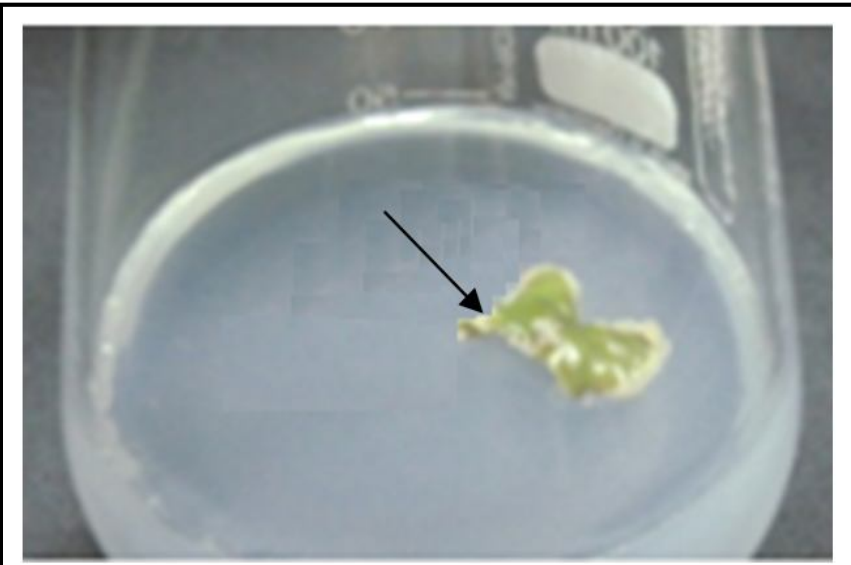

a) Starting of Callus formation (White)

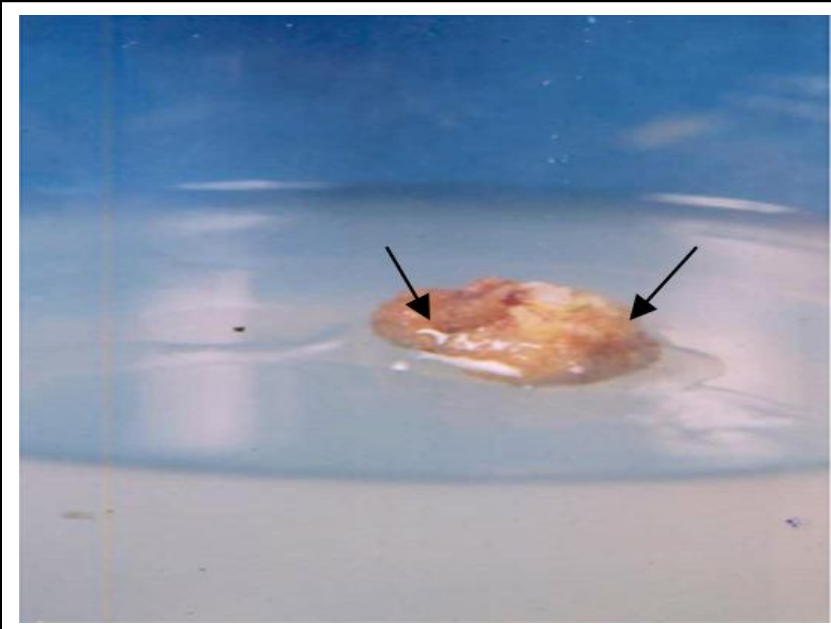

c) Sub-culturing of callus

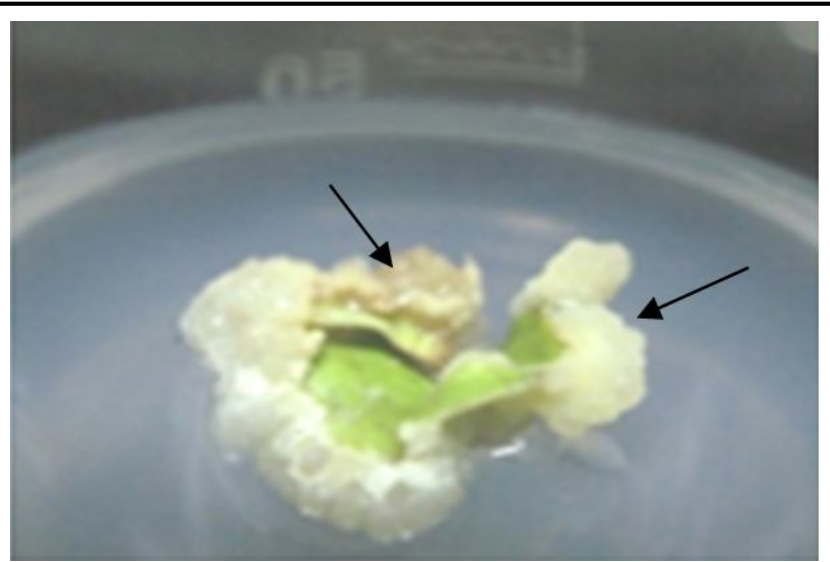

b) Callus enlargement

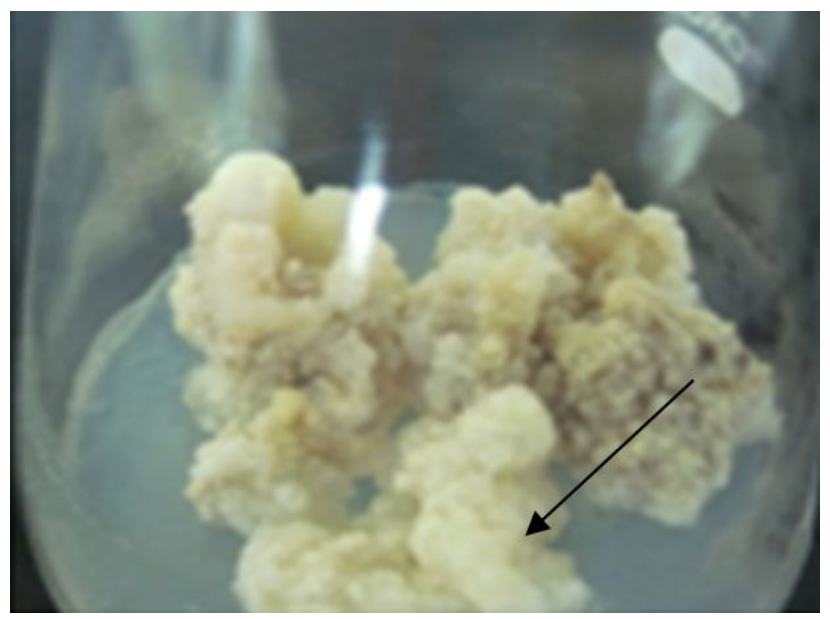

d) Proliferation of callus

Figure 1: (a) and (b)= MS medium supplemented with BAP at $0.2 \mathrm{mg} / 1$ and NAA at $2.5 \mathrm{mg} / 1$ for callus initiation and growth with potassium silicate (c) and $(\mathrm{d})=$ sodium silicate contained MS medium supplemented with BAP at $0.3 \mathrm{mg} / \mathrm{l}$ and NAA at $2.0 \mathrm{mg} / 1$.

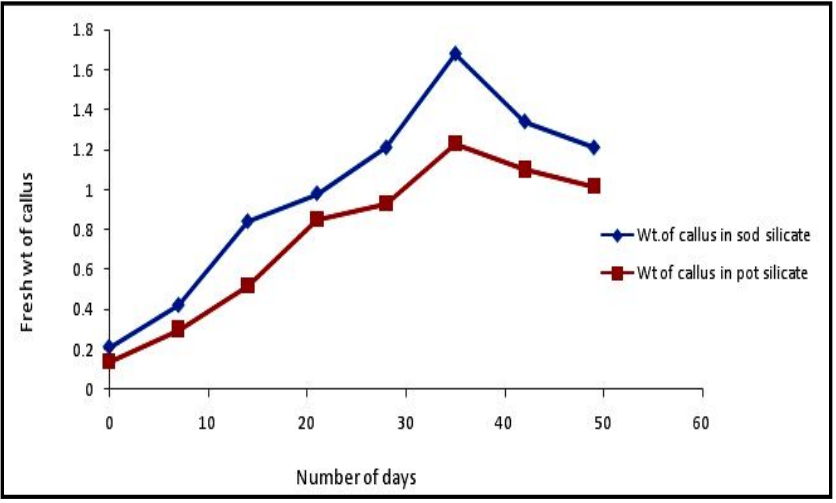

Figure 2: Wt. of fresh callus after sub cultured in MS medium in different days with silicate compound.

\subsection{Extraction of callus}

Methanol solvent was used for extraction of total phenolic and resulted higher yield with callus formed in sodium silicate contained MS medium (Figure 6).

\subsection{HPLC estimation}

Quantification of gallic acid present in the extract of various callus was determined by HPLC analysis. Results revealed showed more content of gallic acid $(0.68 \mathrm{mg} / 100 \mathrm{~g})$ in sodium silicate contained callus which was higher than any other extract (Figures 7 and 8). The retention time (Rt) of gallic acid present in the extract of callus showed the same Rt as per standards gallic acid (3.10 min) (Table 2).

The stock solution of the standard $(1 \mathrm{mg} / \mathrm{ml})$ was diluted to five different concentrations $(5,10,20,40$ and $80 \mu \mathrm{g} / \mathrm{ml})$ and the calibration curve was obtained by plotting peak area versus concentration of the sample. The correlation coefficient of the linearity curve was measured at R2 $>0.997$. The percentage of relative standard deviation (RSD) for standard gallic acid was $<1$.

\subsection{Antioxidant study of callus extracts}

All three different callus were estimated antioxidant activity by DPPH method and result revealed sodium silicate contained MS medium gave higher antioxidant value than normal and potassium silicate contained MS medium. $\mathrm{IC}_{50}$ was calculated with compared with the standard ascorbic acid and result was depicted in Table 3. 


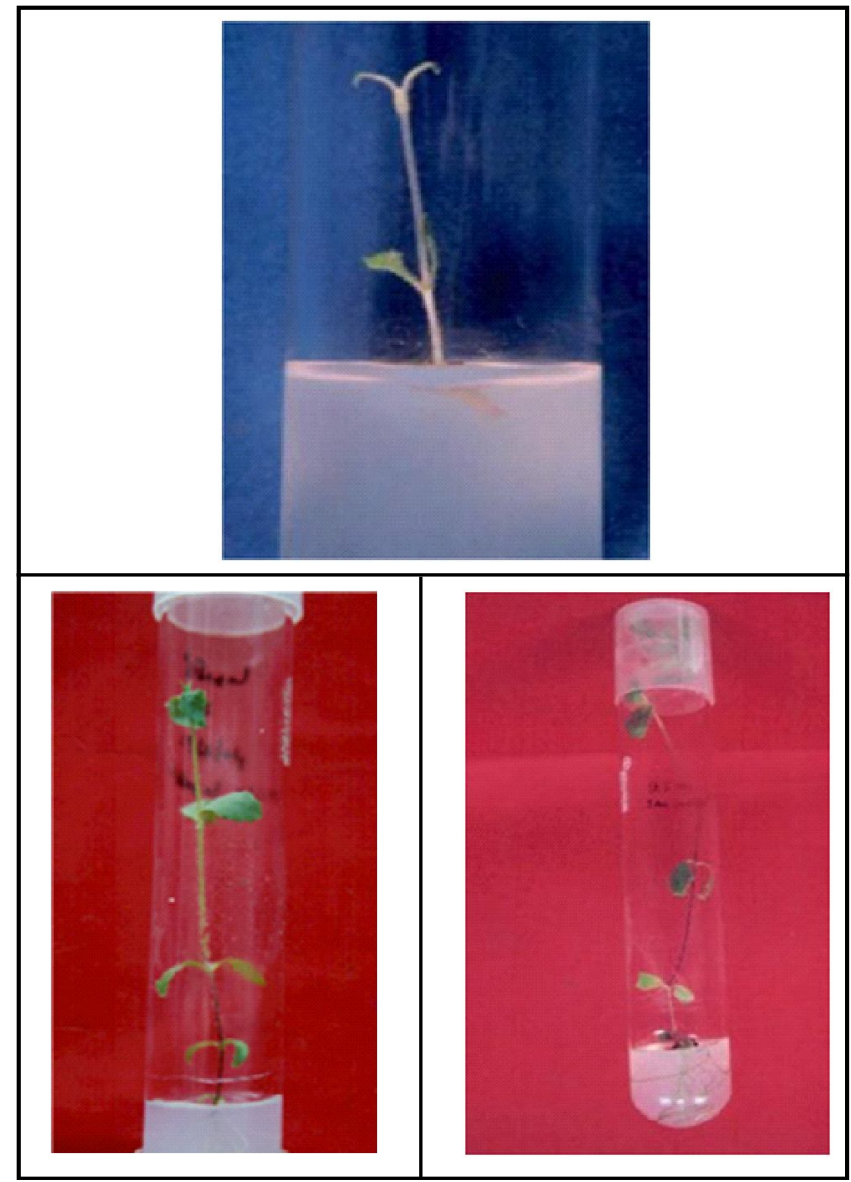

Figure 3: Micropropagation of DN meristem in half strength MS medium (IBA at $2 \mathrm{mg} / 1$ and $\mathrm{K}_{2} \mathrm{SiO}_{3}$ at $2.5 \mathrm{mg} / 1$ and coconut water $5 \% \mathrm{v} / \mathrm{v})$

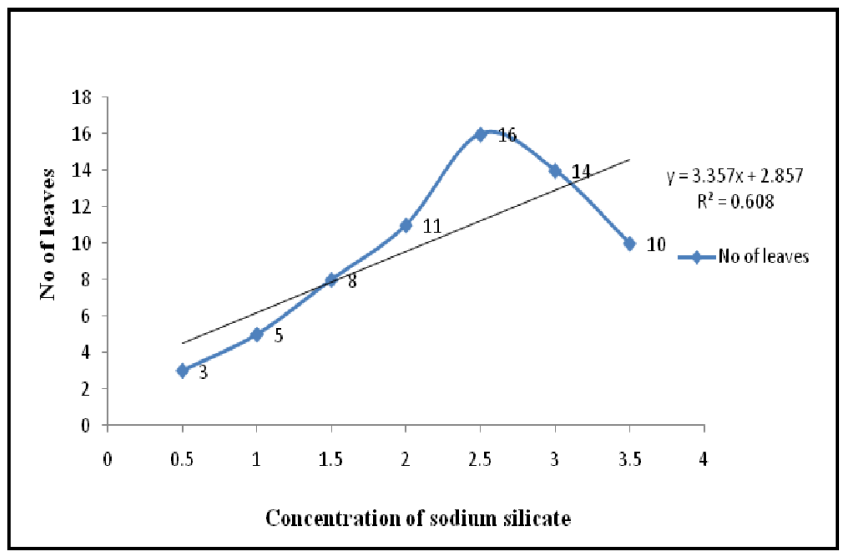

Figure 4: Number of leaves of DN in various concentration of sodium silicate.

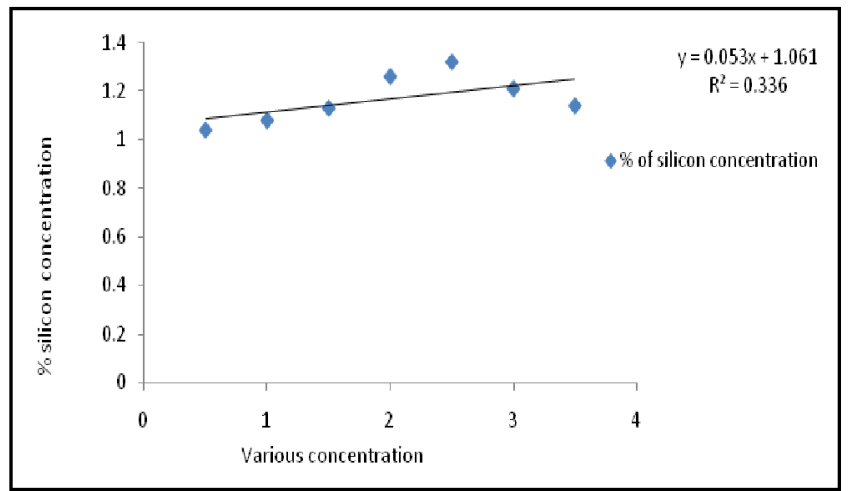

Figure 5: Concentration of silicon in in vitro cultivated leaves of DN by Sod. Silicate supplemented MS medium.

Table 1: Number of roots, length of shoot in various concentrations of hormone in MS medium

\begin{tabular}{|c|c|c|c|c|c|}
\hline Condition & Concentration used & Plant hormone & Concentration & Length of shoots $(\mathrm{cm})$ & No. of roots \\
\hline Sodium silicate & 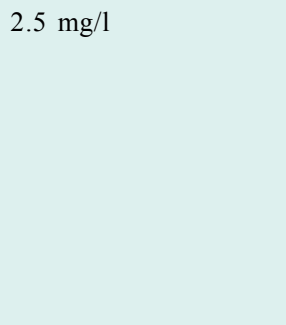 & IBA & $\begin{array}{l}0.5 \\
1.0 \\
1.5 \\
2.0 \\
2.5 \\
3.0 \\
3.5\end{array}$ & $\begin{array}{l}-- \\
03 \pm 0.10 \\
07 \pm 0.11^{*} \\
07 \pm 0.21^{*} \\
07 \pm 0.02 \\
07 \pm 0.13\end{array}$ & $\begin{array}{l}-- \\
02 \pm 0.01 \\
09 \pm 0.13 * * \\
07 \pm 0.11 \\
05 \pm 0.32 \\
05 \pm 0.01\end{array}$ \\
\hline Potassium silicate & $2.5 \mathrm{mg} / 1$ & IBA & $\begin{array}{l}0.5 \\
1.0 \\
1.5 \\
2.0 \\
2.5 \\
3.0 \\
3.5\end{array}$ & $\begin{array}{l}-- \\
02 \pm 0.32 \\
05 \pm 0.12 \\
05 \pm 0.21 \\
05 \pm 0.02 \\
05 \pm 0.11\end{array}$ & $\begin{array}{l}-- \\
04 \pm 0.03 \\
05 \pm 0.12 \\
04 \pm 0.10 \\
04 \pm 0.13 \\
03 \pm 0.02\end{array}$ \\
\hline
\end{tabular}

Mean $\pm \mathrm{SD}(\mathrm{n}=3)$; Other concentration of hormones are not shown in this table. ${ }^{* *} p<0.01 ;{ }^{*} p<0.05$; (Other concentrations of silicate compounds are not showed in table). 


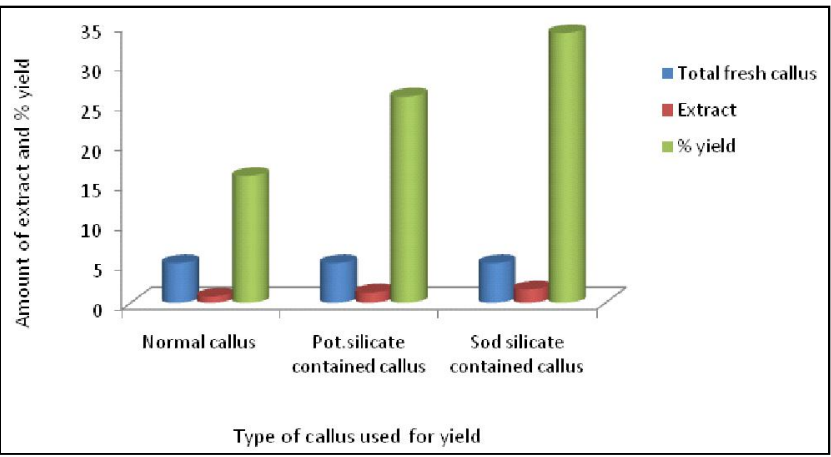

Figure 6: Yield and percentage yield in various callus.

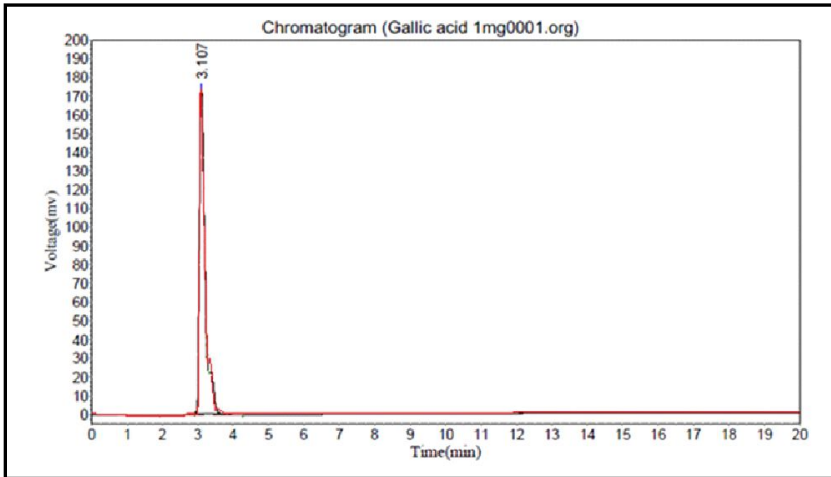

Figure 7: Standard gallic acid.

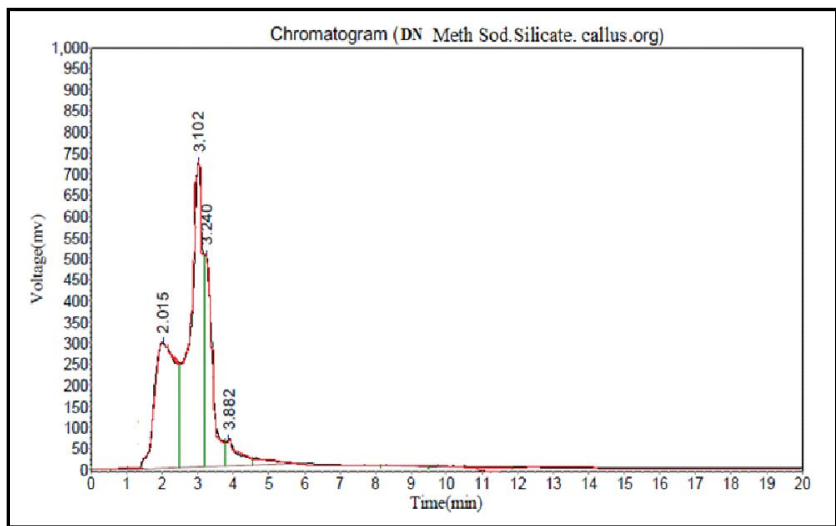

Figure 8: Gallic acid in sod. silicate contained callus methanol extract.

Table 2: Content of gallic acid in various methanol extract of callus

\begin{tabular}{|l|c|c|c|c|}
\hline $\begin{array}{l}\text { Type of } \\
\text { methanol } \\
\text { extract }\end{array}$ & $\begin{array}{l}\text { Gallic acid } \\
(\mathbf{m g} / \mathbf{1 0 0 g})\end{array}$ & $\mathbf{R}^{2}$ & $\%$ RSD & $\begin{array}{c}\text { Rt } \\
\text { (Minute) }\end{array}$ \\
\hline $\begin{array}{l}\text { Normal callus } \\
\text { extract }\end{array}$ & 0.30 & 0.996 & 0.825 & 3.11 \\
$\begin{array}{l}\text { Sod. Silicate } \\
\text { contained } \\
\text { callus extract }\end{array}$ & 0.78 & 0.997 & 0.808 & 3.10 \\
$\begin{array}{l}\text { Pot. Silicate } \\
\text { contained } \\
\text { callus extract }\end{array}$ & 0.57 & 0.997 & 0.812 & 3.12 \\
\hline
\end{tabular}

Table 3: $\mathrm{IC}_{50}$ values of DPPH scavenging effect in various callus methanol extracts

\begin{tabular}{|l|c|}
\hline Extracts & IC $_{\mathbf{5 0}}$ value $(\boldsymbol{\mu g} / \mathbf{m l})$ \\
\hline Ascorbic acid (standard) & $7.64 \pm 0.32$ \\
Normal callus & $17.23 \pm 0.02^{* * *}$ \\
Sod. Silicate contained callus & $11.20 \pm 0.16^{* * *}$ \\
Pot. Silicate contained callus & $13.07 \pm 0.32 * * *$ \\
\hline
\end{tabular}

Mean \pm SD; $(n=3)$, one way ANOVA study, all data compared with standard ascorbic acid; $* * * p<0.001=$ Very high significant.

\subsection{Isolation of DNA from DN callus}

Isolation of DNA was carried out with the callus of sodium silicate contained MS medium. Result showed single isolated DNA with high purity (Figure 9) and further nano drop method was used for quantification and the result showed in Table 3.

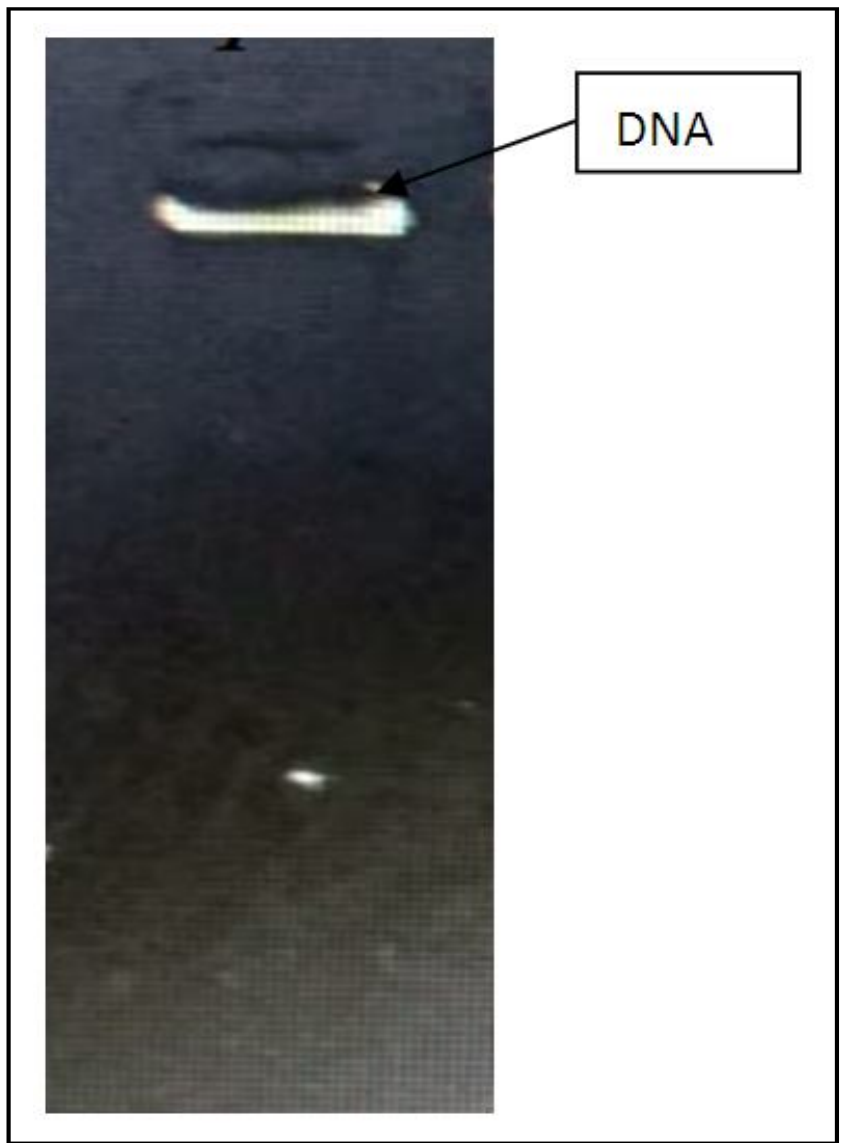

Figure 9: Purified single DNA (Volume loaded $=3 \mu \mathrm{l}$ ).

\subsection{Correlation study}

Based on the previous result, further yield of methanol extract of callus, gallic acid content and silicon content in sodium silicate contained micropropagated leaves was correlated and resulted significant correlation among them (Table 4). The study indicated that yield showed more significant correlation with silicon content in leaves $(p<0.05)$ than content of gallic acid. 
Table 4: Correlation study between yield, gallic acid content and Si content in DN plant

\begin{tabular}{|l|l|l|l|}
\hline & $\begin{array}{l}\text { Yield of extract of sod. } \\
\text { Silicate contained callus }\end{array}$ & $\begin{array}{l}\text { Gallic acid content in sod. } \\
\text { Silicate contained callus }\end{array}$ & $\begin{array}{l}\text { Si content in sod. } \\
\text { Silicate contained micropropagated leaf }\end{array}$ \\
\hline $\begin{array}{l}\text { Yield of extract of sod. } \\
\text { Silicate contained callus }\end{array}$ & 1 & & \\
$\begin{array}{l}\text { Gallic acid content in sod. } \\
\text { Silicate contained callus } \\
\begin{array}{l}\text { Si content in sod. } \\
\text { Silicate contained callus }\end{array}\end{array}$ & $0.974^{*}$ & 1 & 1 \\
\hline
\end{tabular}

${ }^{*} p<0.05=$ Significant $; * p<0.01=$ High significant.

\section{Discussion}

In the present study, silicate compounds (sodium and potassium silicates) were used for the growth of callus of DN leaf disk. It was reported that silicate compounds increase the morphogenetic potential of plant cells, tissues, and organs in an aseptic culture medium. Not only this, Si also significantly affected the antioxidant enzyme activities in many plants by enhanced the growth and morphogenesis (Liang et al., 2007) of enzymes. The addition of Si to the shoot induction medium significantly increased SOD, POD, APX, CAT activity in regenerated shoot buds as compared with the control (Iyyakkannu and Jeong, 2014). Earlier scientific research reports evident for essential function of Si to the tissue culture medium that enhances callus growth, shoot regeneration and root induction, stimulates somatic embryogenesis, and improves morphological, anatomical and physiological characteristics of plantlets, prolongs the longevity of callus and organs with a potential for plant regeneration (Fadl and Reda, 2014; Iyyakkannu and Jeong, 2014). Based on these concepts, the present study was carried out the first time by applied silicate compounds (sodium silicate and potassium silicate), the growth of callus from the leaf disk of DN explant. Callus initiation resulted with potassium silicate $(2.5 \mathrm{mg} / \mathrm{l})$ contained MS medium, supplemented with BAP (at 0.2 $\mathrm{mg} / \mathrm{l}$ ) and NAA (at $2.5 \mathrm{mg} / \mathrm{l}$ ) in 21 days which was also similar with the earlier results (Azra et al., 1997; Dong and Zhan, 2011). Thereafter, sodium silicate helps in the maintenance of callus and its growth and development in MS medium supplemented with BAP at $0.3 \mathrm{mg} / 1$ and NAA at $2.0 \mathrm{mg} / 1$ in 35 days of subcultured callus. A similar observation was also reported earlier when $\mathrm{Si}$ as sodium silicate was added to the modified MS medium, promotes the growth of callus from stem nodal (Sivanesan and Park, 2014). Thereafter, it was reported that the production of gallic acid increased when NAA increased from 0 to $2 \mathrm{mg} / 1$ and the same was reduced when concentration was increased at $2.5 \mathrm{mg} / 1$ of NAA (Dong and Zhan, 2011). Hence, media composition with sodium silicate and supplemented with $0.3 \mathrm{mg} / 1$ of BAP and $2.0 \mathrm{mg} / 1$ of NAA was more appropriate for subculturing and maintenance of callus without browning of callus. The similar result was also reported earlier where a combination of NAA $2 \mathrm{mg} / 1$ and BAP $0.2 \mathrm{mg} / 1$ was suitable for the best cell growth $(19.70 \mathrm{~g}$ dry weight/l) and jaceosidin production $(0.3 \%$ dry weight) in Saussurea medusa (Zhao et al., 2001). 2, 4-D and Kinetin combinations were not suitable for cell growth and gallic acid synthesis (Li et al., 2008) because they produced a fast change in the biomass color (from light yellow to light brown) and hence this combination was not applied in this study. Furthermore, it was reported that callus growth was restricted with an increased in phenolic content and the growth occurred in dark conditions (Hoque and Arima, 2002; Castro et al., 2016). A similar result obtained in the present investigation.

In case of micropropagation, sodium and potassium silicate both showed the positive response for the development of plantlet from the meristem. It resulted that IBA in combination with $\mathrm{Na}_{2} \mathrm{SiO}_{3}$ at specific concentration $(2.5 \mathrm{mg} / \mathrm{l})$, supplemented in half-strength MS media along with coconut water initiated roots and shoot within 18 days and improved the length of roots and shoots after 48 days of subculture but the number of leaves and phenolic content in leaves were decreased with the increased concentration of sodium silicate. The same results also reported by the earlier researchers where increases in the concentration of sodium silicate resulted in significant decreased in the number of leaves of strawberry in vitro culture (Braga et al., 2009) and also Anthurium andraeanum cv. (Dias et al., 2017) plant tissue culture. Thereafter, the shoot length was also depended on applied percentage of coconut water. It was reported that with a higher percentage of the applied coconut water in the medium not significantly increased in the shoot length (Baque et al., 2011) and a similar result followed in the present study where $3 \% \mathrm{v} / \mathrm{v}$ coconut water gave satisfactory shoot growth of DN plantlet. In another study, it resulted that the number of roots were decreased with increased concentration of silicates (Soares et al., 2008) and the similar result observed in the present investigation where the number of roots decreased with the increased concentration of sodium silicate. In the same manner, the silicon content in the leaves of DN was significantly enhanced by the concentrations of sodium silicate wherein $2.5 \mathrm{mg} / \mathrm{l}$ concentration the percentage of phenolics showed more. It was reported that the plants are considered silicon accumulating plants when the silicon levels greater than $1 \%$ in the leaves otherwise they are considered to be non-accumulating plants when silicon levels lower than $0.5 \%$ in the leaves of plants (Ma et al., 2001; Dias et al., 2017). In the present investigation, it was observed that phenol accumulation in the DN leaves was higher than $1 \%$ with the applied silicate in the MS medium which was similar to the earlier evidence. Interestingly, sodium silicate showed a more significant result than potassium silicate because of the higher absorption of sodium than potassium ion in the MS medium (Saheb et al., 2016).

Yield of extract and the percentage yield for all the callus was performed and resulted in higher yield with sodium silicate contained MS medium. The higher yield obtained in methanol extract where more soluble phenolic compounds were extracted. The similar result was also reported by earlier researchers who reported ethanol has been known as a good solvent for polyphenol extraction and is safe for human consumption whereas methanol was better solvent and 
more efficient in extraction of lower molecular weight polyphenols such as gallic acid (Dai and Mumper, 2010; Do et al., 2014).

Quantification of gallic acid was performed by HPLC and revealed the same trend where sodium silicate contained MS medium gave higher estimated amount than other extracts and the result was due to the absorption of phenolics by silicate ion in the callus. Furthermore, the same was also revealed in case of accumulation of gallic acid in the leaves. It was reported that plant hormones NAA and BAP were more proper in the presence of coconut water in the accumulation of gallic acid. In this experiment, added coconut water further helped in the accumulation of gallic acid in the callus which showed synergistic action. The result was similar to the earlier research (Darwesh Hadeer et al., 2015) where coconut milk enhanced the accumulation of phenolics in the callus.

Significant antioxidant activity resulted in all the callus extract $(p<0.001)$ which was due to combined effects of silicate compounds, plant hormones and coconut water, supplemented in the MS medium. Polyphenol compounds are itself acts as an antioxidant and, hence the presence of gallic acid was found more the callus contained silicate compounds and, hence positive synergistic antioxidant activity was reported with the increased content of gallic acid when extracted with methanol. The present result was also correlated with the earlier literature (Sunitha et al., 2013; Ibrahim et al., 2018; Sekeroglu and Gezici, 2019).

Isolation of DNA from the callus was carried out and resulted in one single band purified DNA and further quantified at two different wavelengths in UV spectrophotometer. The ratio of absorbance at $260 \mathrm{~nm}$ and $280 \mathrm{~nm}$ was used to assess the purity of DNA. A ratio of $\sim 1.8$ is generally accepted as "pure" for DNA. If, the ratio was appreciably lower in either case, it was indicated that the presence of protein, phenol or other contaminants that absorb strongly at or near $280 \mathrm{~nm}$. Thereafter, 260/230 ratio was used as a secondary measure of nucleic acid purity. The $260 / 230$ values for "pure" nucleic acid are often higher than the respective 260/280 values. Expected $260 / 230$ values were commonly in the range of $2.0-2.2$. If, the ratio was appreciably lower than expected, it was indicated the presence of contaminants which absorb at $230 \mathrm{~nm}$. The study helped to know about the genomic polymorphism of the said plant. In earlier literature also studied the same to identify DNA from the callus extract of carpobrotus species (Diadema et al., 2003). This study will further help the researchers for the beneficial utilization of DN plant in various therapeutic efficacies.

Finally, correlation study revealed a significant result when compared silicon and gallic acid content with the yield and silicon content with gallic acid content. A positive significant correlation was observed that established valid scientific evidence for the aim of the present investigation.

\section{Conclusion}

The results finally concluded that callus and micropropagation of the DN plant successfully carried out through in vitro cultured method, using sodium and potassium silicate compound and further the activity was boosted with the applied coconut water $(3 \% \mathrm{v} / \mathrm{v})$ in MS medium. Callus initiation was observed with potassium silicate contained MS medium, supplemented with BAP and NAA plant hormone whereas the same was subcultured and callus growth was maintained with sodium silicate contained MS medium without browning of callus. Thereafter, shoot length, the number of roots and fresh callus weight, silicon content in leaves were increased with sodium silicate contained MS medium that also associated with high antioxidant activity. Pure DNA was isolated and quantified at various wavelengths and revealed easy manipulation of genelevel for better therapeutic efficacies in the near future.

\section{Conflict of interest}

The authors declare that there are no conflicts of interest in the course of conducting the research. All the authors had final decision regarding the manuscript and decision to submit the findings for publication.

\section{Acknowledgements}

Authors are thankful to Rajiv Gandhi University of Health Sciences, Bangalore for financial assistance towards research grant (Principal Investigator) for carry out the present investigation (Order No: RGU:RGU/ADV.RES/BR/001/2017-18).

\section{References}

Anitha, S. and Pullaiah, T. (2002). In vitro propagation of Decalepis hamiltonii. J. Trop. Med. Plants, 3:227-232.

Anonymous (1962). The Wealth of India: A dictionary of Indian raw materials and industrial products. New Delhi, India: 6th Vol. Publication and Information Directorate (CSIR).

Anonymous (2000). Ethnobiology in India: A status report. All India Coordinated Research Project in Ethnobiology. Ministry of Environment and Forests, New Delhi, Government of India.

Anonymous (2003). The wealth of India: A dictionary of Indian raw materials and industrial products. CSIR, New Delhi, 3:24.

Azra, Q.; Iqbal, H.; Mushtaq, A.; Hamid, R. and Muhammad, L. (1997). Sustained multiplication of long term embryogenic cultures of date palm and their field performance. Pakistan J. Botany, 29(1):135-141.

Bais, H.P.; Sidha, G.; Suresh, B. and Ravishankar, G.A. (2000). $\mathrm{AgNO}_{3}$ influences in vitro root formation in Decalepis hamiltonii Wight \& Arn. Curr. Sci., 79:894-898.

Baque, M.A.; Shin, Y.K.; Elshmar, T.; Lee, E.J. and Paek, K.Y. (2011). Effect of light quality, sucrose and coconut water concentration on the microporpagation of Calanthe hybrids ('Bukduseong' $\times$ 'Hyesung' and 'Chunkwang' $\times$ 'Hyesung'). Australian Journal of Crop Science, 5(10):1247-1254

Braga, F.T.; Nunes, C.F.; Favero, A.C.; Pasqual, M.; Carvalho, J.G. and Castro, E.M. (2009). Anatomical characteristics of the strawberry seedlings micropropagated using different sources of silicon. Pesquisa Agropecuária Brasileira, 44:128-132.

Castro, A.H.F.; de Queiroz Braga, K.; de Sousa, F.M.; Coimbra, M.C. and Chagas, R.C.R. (2016). Callus induction and bioactive phenolic compounds production from (Byrsonima verbascifolia L.) DC. (Malpighiaceae). Revista Ciência Agronômica, 47(1):143-151.

Dai, J. and Mumper, R.J. (2010). Plant phenolics: Extraction, analysis and their antioxidant and anticancer properties. Molecules, 15:7313-7352.

Dave, A. and Purohit, S. D. (2002). Factors influencing in vitro culture of Safed musli (Chlorophytum borivilianum). Oikoassay, 15:19-27.

Diadema, K.; Baumel, A.; Lebris, M. and Affre, L. (2003). Genomic DNA isolation and amplification from callus culture in succulent plants, Carpobrotus species (Aizoaceae). Plant Mol. Biol. Rep., 21(2):173. https://doi.org/10.1007/BF02774244. 
Darwesh Hadeer, Y.A.; Nour El-Deen, A.H. and Fayad Eman, M. (2015). In vitro Investigation for improving secondary metabolites in Origanum vulgare plants using tissue culture technique at taif Governorate, KSA. Research Journal of Pharmaceutical, Biological and Chemical Sciences, 6(5):1117-1122.

Das, K.; Saifulla Khan, M.; Namratha, N.; Swetha, R. and Gezici, S. (2019). Comparative phytochemical screening, elemental content and chromatographic evaluation for detection and quantification of polyphenolic compounds for strong antioxidant activity of various extracts of Abutilon indicum (Link) sweet leaves. Ann. Phytomed., 8(1):36-44

Debnath, M.; Malik, C.P. and Bisen, P.S. (2006). Micropropagation: A tool for the production of high quality plant-based medicines. Current Pharmaceutical Biotechnology, 7:33-49.

Dias, G.M.G; Soares, J.D.R.; Ribeiro, S.F.; Martins, A.D.; Pasqual, M. and Alves, E. (2017). Morphological and physiological characteristics in vitro anthurium plantlets exposed to silicon. Crop Breeding and Applied Biotechnology, 17:18-24.

Do, Q.D.; Angkawijaya, A.E.; Nguyen, P. L.T.; Huynh, L.H.; Soetaredjo, F.E.; Ismadji, S. and Ju, Y.H. (2014). Effect of extraction solvent on total phenol content, total flavonoid content, and antioxidant activity of Limnophila aromatic. Journal of Food and Drug Analysis, 22(3):296-302.

Doyle, J. and Doyle, J. (1987). A rapid procedure for DNA purification from small quantities of fresh leaf tissue. Phytochem. Bull., 19:11-15.

Duncan, D.B. (1955). Multiple range and multiple F tests. Biometrics, 11: $1-42$.

Fadl, A. E. and Reda, I. (2014). Effect of silicon on somatic embryogenesis and shoot regeneration of dry date palm (Phoenix dactylifera 1.) CV Bartamuda. Egyptian J. Desert Res., 64:65-82.

Gallo, J.R. and Furlani, P.R. (1978). Determination of silicon in plant material by molybdenum blue colorimetric method. Bragantia., 37:5-11

Giridhar, P.; Rajasekaran, T. and Ravishankar, G.A. (2005). Improvement of growth and root specific flavour compound 2-hydroxy-4-methoxy benzaldehyde of micropropagated plants of Decalepis hamiltonii Wight \& Arn., under triacontanol treatment. Sci. Hort., 106:228-236.

Healey, A.; Furtado, A.; Cooper, T. and Henry, R.J. (2014). Protocol: A simple method for extracting next-generation sequencing quality genomic DNA from recalcitrant plant species. Plant Methods, 10:21.

Hoque, A. and Arima, S. (2002). Overcoming phenolic accumulation during callus induction and in vitro organogenesis in water chestnut (Trapa japonica Flerov). In vitro cellular and developmental biology. Plant, 38(4):342-346.

Ibrahim, M.M.; Arafa, N.M. and Aly, U.I. (2018). Antioxidant activity, pheno and flavonoid contents of plant and callus cultures of Plectranthus barbatus Andrews. Egypt Pharmaceut. J., 17:32-39.

Ionta, G.M. (2009). Phylogeny reconstruction of periplocoideae (apocynaceae) based on morphological and molecular characters and a taxonomic revision of Decalepis. The Ph.D. Thesis, University of Florida.
Iyyakkannu, S. and Jeong, B.R. (2014). Silicon promotes adventitious shoot regeneration and enhances salinity tolerance of Ajuga multiflora Bunge by altering activity of antioxidant enzyme. The Scientific World Journal, Article ID 521703.

Jacob, K.C. (1937). An unrecorded economic product Decalepis hamiltonii W. \& Arn., family Asclepiadaceae. Madras Agric. J., 25:176.

Jiang, W.L. and Yang, Z.W. (2010). Inhibitive effects of EGCG on the proliferation of human prostate cancer cell line PC-3. Med. J. Wuhan. Univ., 31(3):317-319.

Li, H.Y.; Song, J.Y.; Dong, J. and Zhan, Y.G. (2008). Establishment of callus regeneration system for Acer ginnala Maxim and determination of gallic acid in callus. Chin. Bull. Bot., 25(2):212-219.

Liang, Y.; Sun, W.; Zhu, Y. and Christie, P. (2007). Mechanisms of silicon mediated alleviation of a biotic stresses in higher plants a review. Environmental Pollution, 147:422-428.

Ma, J.F.; Miyake, Y. and Takahashi, E. (2001). Silicon as a beneficial element for crop plant. In Datnoff LE, Korndörfer GH and Snyder G (eds). Silicon in agriculture. Elsevier Science, New York, pp:17-39.

Murashige, T.and Skoog, T. (1962). A revised medium for rapid growth requirements of tabacco tissue cultures. Physiol. Plantarum., 15: 473-497.

Murti, P.B. and Seshadri, T.R. (1941). A study of the chemical components of the roots of Decalepis hamiltonii (Makali veru). Part IV- Resinol of Decalepis hamiltonii and Hemidesmus indicus. Proc. Ind. Acad. Sci. A., 14:93-99.

Saheb, M.; Hanafi, M.M. and Azizi, P. (2016). Application of silicon in plant tissue culture. In vitro Cell. Dev. Biol. Plant, 52:226-232.

Sekeroglu, N. and Gezici, S. (2019). Astragalus neurocarpus Bioss. as a potential source of natural enzyme inhibitor associated with Alzheimer's and Parkinson diseases along with its rich polyphenolic content and antioxidant activities. Ann. Phytomed., 8(1):82-87.

Sivanesan, I. and Park, S.W. (2014). The role of silicon in plant tissue culture. Front Plant Sci., 5:571

Soares, J.D.R.; Pasqual, M.; Rodrigues, F.A.; Villa, F. and Carvalho, J.G. (2008). Silicon fertilization via leaf in the acclimatization of an Orchid hybrid. Ciência and Agrotecnologia., 32:626-629.

Sunitha, K.; Chary, K.B.; Nimgulkar, C.C.; Kumar, B.D. and Manohar-Rao, D. (2013). Identification, quantification and antioxidant activity of secondary metabolites in leaf and callus extracts of Coleus forskohlii. Int. J. Pharm. Bio. Sci., 4:1139-1149.

Udayan, P.S.; Robi, A. J. and Anilkumar, K.A. (2013). Decalepis nervosa (Apocynaceae, Periplocoideae): A rare and little known endemic plant from Kerala. Nelumbo, 55:188-190.

Zhang, W.J.; Xiong, D.Y. and Liu, X.M. (2010). Study on the preparation of trisacetyl-galloylchloride from gallic acid. Appl. Chem. Ind., 39(12):1849-1856.

Zhao, D.; Xing, J.; Li, M.; Lu, D. and Zhao, Q. (2001). Optimization of growth and jaceosidin production in callus and cell suspension cultures of Saussurea medusa plant Cell, Tissue Organ. Culture, 67:227234.

Citation: M. Saifulla Khan, Kuntal Das and P. E. Rajasekharan (2019). Chromatographic quantification of polyphenol in relation to potential antioxidant activity and isolation of DNA from in vitro cultivated Decalepis nervosa Wight \& Arn. leaf explant. Ann. Phytomed., 8(2):141-149. 